\title{
Pembuatan Sediaan Tabir Surya Ekstrak Etanol Buah Mahkota Dewa (Phaleria macrocarpa), Aktivitas Inhibisi Fotodegradasi Tirosin dan Kandungan Fenolik Totalnya
}

\author{
Formulation of Mahkota Dewa (Phaleria macrocarpa) Fruit Extract Sunscreen, \\ Inhibition Activity of Tyrosine Photodegradation and its Total Phenolic \\ Compounds
}

Tatang Irianti1 ${ }^{*}$, T.N. Saifullah Sulaiman', Nanang Fakhrudin', Siluh Astuti ${ }^{1}$, Nita

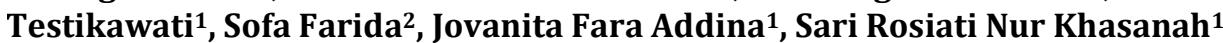

${ }^{1}$ Fakultas Farmasi, Universitas Gadjah Mada

2 Balai Besar Penelitian dan Pengembangan Tanaman Obat Tradisional, Badan Penelitian dan Pengembangan Kesehatan

Corresponding author: Tatang Irianti: Email: intanti@ugm.ac.id

Submitted: 04-04-2019 Revised: 12-06-2019

Accepted: 12-06-2019

\begin{abstract}
ABSTRAK
Senyawa fenolik mempunyai potensi sebagai fotoprotektor, sehingga mampu melindungi kulit dari kerusakan oksidatif terutama menyerap Ultra Violet dari pancaran sinar matahari. Ekstrak etanolik buah masak mahkota dewa [Phaleria macrocarpa (Scheff) Boerl.] mengandung senyawa fenolik dan memiliki peranan sebagai fotoprotektor. Penelitian ini bertujuan untuk mengetahui efektivitas ekstrak etanolik buah mahkota dewa sebagai fotoprotektor dalam sediaan tabir surya dan oksibenson sebagai pembanding. Aktivitas fotoprotektor ditentukan dari tingkat fotodegradasi tirosin dan kadar fenolik totalnya, kemudian penelitian ini dilakukan dengan 8 formula; formula 1 sebagai kontrol negatif (basis); formula 2 sebagai kontrol positif (basis dan oksibenson); formula 3 , formula 4, dan formula 5 mengandung ekstrak etanolik buah mahkota dewa dengan berbagai konsentrasi; formula 6 , formula 7 , dan formula 8 mengandung oksibenson dan ekstrak etanolik buah mahkota dewa dengan berbagai konsentrasi. Penentuan kemampuan fotoproteksi berdasarkan persen transmisi eritema dan persen transmisi pigmentasi. Uji inhibisi fotodegradasi dilakukan dengan menggunakan enam kelompok komposisi tirosin dan Rhetoflam. Uji penentuan ka dar fenolik total dilakukan menggunakan metode Follin-Ciocalteu. Hasil pengukuran diintrapolasikan ke dalam kurva baku asam galat. Ekstrak etanolik buah mahkota dewa dalam sediaan tabir surya memberikan nilai Te sebesar 17,86-37,01 \% dan nilai Tp sebesar 12,07-22,64 \%. Efektivitas fotoproteksi ekstrak etanolik buah mahkota dewa lebih kecil dibandingkan oksibenson yang memiliki nilai Te sebesar 1,15.10-5 \% dan Tp sebesar 0,67 \%. Kombinasi ekstrak etanolik buah mahkota dewa dan oksibenson memberikan nilai Te sebesar 0,17-0,52 \% dan nilai Tp sebesar 2,10-4,48 \%. Sedangkan kandungan fenolik total ekstrak buah mahkota dewa adalah sebesar 8,29 $\pm 0,27 \%$ dengan aktivitas penghambatan fotodegradasi tirosin 1,58 kali lebih besar dibandingkan dengan vitamin C pada kadar yang sama, yaitu $0,15 \%$. Hal ini menunjukkan bahwa ekstrak etanolik buah mahkota dewa dapat dimanfaatkan sebagai bahan 4aktif fotoprotektor dalam sediaan kosmetik.
\end{abstract}

Kata kunci: Mahkota Dewa, Fotorproteksi, Fotodegradasi, Tabir Surya

\section{ABSTRACT}

The phenolic compounds play an important role for photoprotector on the skin against sunlight or ultra violet light. Mahkota dewa [Phaleria macrocarpa (Scheff) Boerl.] fruit contains phenolic compounds and has potential as a photoprotector. Sunscreen lotion or cream can be decreased the intensity of UV radiation reaching the skin and then the risk of sun-induced skin cancer is smaller. The present study attempt to develop possessing broad spectrum of anti-UV radiation effectiveness with reduced concentration of chemical UV-filters. Sunscreen formulation of mahkota dewa extract were compared to oxybenson and determined the photodegradation activity of tyrosine. Furthermore, the total phenolic concentration is analyzed as the active compound in the photoprotector. The effectiveness of formulation was evaluated using the percent of erythema 
transmission (Te) and pigmentation transmission (Tp). The sunscreen creams were prepared using 8 different composition F1 up to F8; formula 1 as negative control (base); formula 2 as a positive control (base and oxybenson); formula 3, formula 4, and formula 5 contained ethanolic extract of mahkota dewa fruit with various concentrations; formula 6, formula 7, and formula 8 contained oxybenson and ethanolic extract of mahkota dewa fruit with various concentrations. Determination of photoprotector ability based on percent transmission of erythema and percent pigmentation transmission. The photodegradation inhibition test was carried out using six groups of tyrosine and Rhetoflam compositions. The investigation of total phenolic level test was carried out using the Follin-Ciocalteu method. The measurement results are intrapolated into the standard curve of gallic acid. The ethanolic extract mahkota dewa fruit in sunscreen preparations gave a Te value of 17.86$37.01 \%$ and a TP value of $12.07-22.64 \%$. The effectiveness of photoprotection of the ethanolic extract is smaller than oxybenson which has a Te value of $1.15 .10-5 \%$ and $\mathrm{Tp}$ of $0.67 \%$. The combination of ethanolic extract and oxybenson gave Te values of $0.17-0.52 \%$ and $\mathrm{Tp}$ values were $2.10-4.48 \%$. Whereas the total phenolic content of mahkota dewa fruit extract was $8.29 \pm 0.27 \%$ with inhibition of tyrosine photodegradation activity 1.58 times greater than vitamin $\mathrm{C}$ at the same level, which is $0.15 \%$. This shows that mahkota dewa ethanolic extract can be used as an active ingredient of photoprotector in cosmetic preparations.

Keywords: Mahkota Dewa, Photoprotection, Photodegradation, Sun Protection

\section{PENDAHULUAN}

Indonesia merupakan daerah tropis dengan intensitas paparan sinar matahari yang tinggi, seperti UV A dan UV B. Hal ini dapat menimbulkan pengaruh buruk bagi kulit, termasuk kanker kulit. Cahaya matahari merupakan energi dalam bentuk gelombang elektromagnetik. Energi foton dari cahaya matahari dapat menimbulkan perubahan fotokimia sehingga dapat menyebabkan perubahan metabolisme pada makhluk hidup (Koechevar et al., 1993) dan berakibat pada perubahan metabolisme, kerusakan sel, mutasi sel bahkan kematian sel (Koechevar et al., 1993). Radiasi sinar matahari dapat memicu timbulnya radikal bebas reaktif dan mudah bereaksi dengan jaringan sehingga dapat menimbulkan kerusakan oksidatif terutama pada jaringan kulit (Halliwel, B. \& Gutteridge, 1999). Efek lain dari sinar matahari adalah terjadinya sunburn (kulit terbakar), kulit kemerahan, bahkan terjadi kerusakan oksidatif apabila terjadi paparan secara terus-menerus (Wasitatmadja, S., 1997).

Senyawa fenolik dalam tumbuhan mempunyai aktivitas antioksidan (Svobodova et al., 2003) dan juga dapat digunakan sebagai fotoprotektor untuk melindungi jaringan tubuh dari kerusakan akibat paparan sinar matahari (Halliwel, B. \& Gutteridge, 1999). Senyawa antioksidan dapat mengurangi reaksi oksidasi yang ditimbulkan oleh beragam agen oksidatif. Vitamin C, vitamin E, dan flavonoid merupakan beberapa antioksidan penting dan banyak digunakan dalam sediaan kosmetik (Barel et al., 2001).

Adanya berbagai macam dampak negatif akibat paparan sinar matahari berlebih menyebabkan kita perlu menggunakan fotoprotektor untuk melindungi kulit dari kerusakan akibat radiasi matahari. Fotoprotektor adalah suatu agen atau senyawa yang dapat melindungi kulit dari pengaruh buruk cahaya matahari, seperti terbakar surya, eritema, kerusakan sel, mutasi sel atau kematian sel. Idealnya fotoprotektor dikatakan baik apabila tidak hanya mencegah eritema tetapi juga mencegah kanker dan kerusakan kulit.

Salah satu fotoprotektor alami berupa golongan senyawa fenolik khususnya senyawa flavonoid dimana banyak terdapat dalam tumbuhan dan berfungsi untuk melindungi jaringan tumbuhan terhadap kerusakan akibat radiasi sinar matahari (Halliwel, B. \& Gutteridge, 1999). Mahkota dewa mengandung senyawa fenolik berupa flavonoid dengan kemampuan sebagai antioksidan serta sebagai fotoprotektor (Zin et al., 2004). Senyawa fenolik dalam tanaman ini memiliki ikatan rangkap terkonjugasi sehingga mampu menyerap sinar UV.

Efek buruk dari paparan sinar matahari dapat dicegah, salah satunya dengan cara menggunakan tabir surya. Tabir surya merupakan suatu sediaan kosmetik dan berfungsi sebagai pelindung tambahan bagi tubuh terhadap paparan sinar matahari 
berlebih (Wilkinson, J. B., \& Moore, 1982). Tabir surya dengan kombinasi oksibenson dapat berperan baik sebagai anti-UV A. Oksibenson dapat menyerap UV A dengan baik sebagai proteksi, pada cakupan panjang gelombang 320$360 \mathrm{~nm}$ dan konsentrasi umum yang digunakan adalah 2-6\% b/b (Shaath, 1990). Kemampuan mahkota dewa sebagai agen penyerap sinar UV dan penangkal radikal bebas dapat dimanfaatkan sebagai komponen utama dalam pembuatan tabir surya. Sediaan kosmetik untuk tabir surya dapat berupa salep atau sediaan semipadat digunakan untuk pemakaian pada kulit atau membran mukosa (Sulaiman, T.N.S., \& Kuswahyuning, 2008).

Pigmentasi pada kulit terjadi akibat adanya proses sintesis melanin, sintesis melanin terpicu oleh adanya sinar matahari karena melanin merupakan agen perlindungan tubuh alami terhadap paparan sinar matahari. Pigmen melanin dapat ditemukan di bagian tubuh manusia maupun hewan, berfungsi sebagai fotoprotektor untuk mengurangi jumlah bahaya radiasi UV pada kulit. Pigmen melanin dianggap sebagai turunan dari tirosin, tersusun dari asam amino dan digunakan sel untuk sintesis protein. Kemampuan mahkota dewa sebagai agen penyerap UV dan penangkal radikal bebas dapat diproyeksikan dalam perhitungan besarnya aktivitas inhibisi (penghambatan) forodegradasi dari tirosin dibandingkan dengan vitamin C.

Sifat antioksidan pada tanaman mahkota dewa terdapat pada senyawa flavonoid dan polifenol (Zin et al., 2004). Penambahan ekstrak etanolik mahkota dewa diharapkan dapat menurunkan \% transmisi eritema dan \% transmisi pigmentasi sediaan tabir surya serta dapat digunakan sebagai fotoprotektor. Penentuan kadar fenolik total dan aktivitas inhibisi fotodegradasi tirosin diharapkan memberikan nilai yang baik dalam kaitannya sebagai fotoprotektor.

\section{METODOLOGI Bahan}

Bahan yang digunakan dalam penelitian ini adalah: buah mahkota dewa, tirosin (Wako Pure), oksibenson (atas jasa PT. Vitapharm), asam stearat (Brataco), setil alkohol (Brataco), span 60 (Brataco), tween 60 (Brataco), larutan sorbitol (Brataco), metil paraben (Brataco), dan propil paraben (Brataco), aquades (General Lab), isopropanol (p.a. E.Merck) dan etanol (p.a.
E.Merck), etanol 70\% (teknis, General Lab), lempeng KLT siliks gel $\mathrm{GF}_{254}$ (E.Merck), rutin trihydrate (Fluka Biochemika), ketoprofen topikal merk Rhetoflam ${ }^{\circledR} 25 \mathrm{mg}$ (Kimia Farma), vitamin $\mathrm{C}$ (E. Merck), $\mathrm{HgSO}_{4}$ (E. Merck) $\mathrm{H}_{2} \mathrm{SO}_{4}$ (E. Merck), $\mathrm{NaNO}_{2}$ (E. Merck), $\mathrm{NaOH}$ (E. Merck), reagen Folin-Ciocalteu (E. Merck), $\mathrm{Na}_{2} \mathrm{CO}_{3}$ (E. Merck), dan $\mathrm{C}_{2} \mathrm{H}_{5} \mathrm{OH}$ (E. Merck).

\section{Alat}

Alat yang digunakan dalam penelitian ini adalah: cawan porselen, kertas $\mathrm{pH}$, alat uji daya lekat, alat uji daya sebar, viscotester (Rion VT04), sentrifuge (Hettich), spektrofotometer (Hitachi U-2800), neraca analitik (Ohoaus), waterbath (memmert), stopwatch, vortex (Maxi Mix Plus TM), spektrofotometer (Genesys-10), panci infusa, stopwatch (Nokia ${ }^{\circledR} 3330$ ),

vortex (Maxi Mix Plus TM), mikropipet (Trasferpette ${ }^{\circledR}$ ), spektrofotometer (Genesys10), lampu merkuri (Sankyo Denki 20 watt), dan waterbath (Memmert ${ }^{\circledR} \mathrm{GmbH}+$ Co. KG), kompor listrik (Robusta ${ }^{\circledR}$ ), yellow tip, blue tip, dan seperangkat alat gelas.

\section{Jalannya Penelitian}

Determinasi Tanaman

Dilakukan oleh Bagian Biologi Farmasi, Fakultas Farmasi Universitas Gadjah Mada Yogyakarta, menyatakan kebenaran tanaman mahkota dewa (Phaleria macrocarpa (Scheff.) Boerl).

Ekstraksi Simplisia Buah Mahkota Dewa

Sebanyak 600 gram serbuk buah mahkota dewa dimaserasi dengan cara direndam dalam bejana maserator menggunakan 4,5 L etanol 70\% selama 4 hari dengan sesekali dilakukan pengadukan. Maserat dipisahkan dari serbuk dengan penyaringan menggunakan kain flannel, kemudian maserat diuapkan diatas penangas air hingga diperoleh ekstrak kental buah mahkota dewa. Ekstrak kental yang diperoleh ditimbang dan dihitung randemennya. Sedangkan, ekstrak air buah mahkota dewa didapatkan dengan metode infundasi.

\section{Penetapan Kadar Fenolik Total}

Penetapan kadar fenolik total ekstrak buah mahkota dewa dilakukan dengan metode Folin-Ciocalteu. Untuk kurva dibuat larutan induk (Li) asam galat dengan konsentrasi 
Tabel I. Formula Basis Emulsi Menggunakan Surfaktan Non-ionik Menurut Lachman et al., 1994 dengan Beberapa Pengembangan

\begin{tabular}{lcccc}
\hline \multicolumn{1}{c}{ Komponen } & F1(\%) & F2(\%) & F3(\%) & F4(\%) \\
\hline Asam stearate & 14 & 14 & 14 & 14 \\
Setil alcohol & 1 & 1 & 1 & 1 \\
Span 60 & 2 & 1,5 & 3,5 & 0 \\
Tween 60 & 1,5 & 2 & 0 & 3,5 \\
Larutan sorbitol 70\% & 3 & 3 & 3 & 3 \\
Metilparaben & 0,1 & 0,1 & 0,1 & 0,1 \\
Propilparaben & 0,05 & 0,05 & 0,05 & 0,05 \\
Ekstrak mahkota dewa & 6 & 6 & 6 & 6 \\
Aquadest & ad 100 & ad 100 & ad 100 & ad 100 \\
\hline
\end{tabular}

$1 \mathrm{mg} / \mathrm{ml}$ dalam etanol. Sebanyak $10 ; 20 ; 30 ; 40$; 50; 60; dan $70 \mu \mathrm{l} \mathrm{Li} \mathrm{dimasukkan} \mathrm{dalam} \mathrm{labu}$ takar $10 \mathrm{ml}$, ditambah dengan $0,4 \mathrm{ml}$ reagen Folin-Ciocalteu, dan dibiarkan selama 5-8 menit. Selanjutnya larutan ini ditambah dengan $\mathrm{Na}_{2} \mathrm{CO}_{3} 7 \%$ sebanyak $4 \mathrm{ml}$ dan ditambah aquadest sampai batas tanda. Setelah 2 jam, absorbansinya dibaca pada panjang gelombang $750 \mathrm{~nm}$. Dilakukan juga pembacaan blangko yang terdiri atas aqua bidestilata dan reagen Folin-Ciocalteu. Penentuan kandungan fenolik total sampel, diambil $75 \mu \mathrm{l}$ ekstrak buah mahkota dewa 1\% dan dilanjutkan sebagaimana perlakuan pada pembuatan kurva baku. Pengukuran dilakukan replikasi sebanyak enam kali.

\section{Uji Pendahuluan}

Pembuatan Formula

Fase air terdiri dari larutan sorbitol $70 \%$, Tween 60, dan ekstrak buah mahkota dewa. Fase minyak terdiri dari asam stearat, setil alkohol, dan Span 60. Panaskan fase air dan fase minyak hingga suhu $80^{\circ} \mathrm{C}$. Fase air ditambahkan ke dalam fase minyak sedikit demi sedikit sambil diaduk. Campuran dimasukkan ke dalam campuran metilparaben dan propilparaben yang telah digerus didalam mortir sambil terus diaduk. Air ditambahkan sedikit demi sedikit sambil diaduk ke dalam campuran sampai formula mencapai 100\%. Formula yang digunakan untuk membuat basis (Tabel I).

Uji Mutu Fisik Pendahuluan

Uji mutu fisik meliputi pengamatan penampilan sediaan krim yang dibuat, warna, bau, viskositas, fase distribusi, $\mathrm{pH}$, dan tekstur.

\section{Daya Sebar Basis}

Sebanyak 0,5 gram basis diletakkan di tengah alat (kaca bulat). Kaca penutup ditimbang, kemudian diletakkan di atas basis, dibiarkan selama 1 menit. Diameter penyebaran basis diukur dengan mengambil panjang rata-rata diameter dari beberapa sisi. Beban tambahan seberat 50 gram diletakkan di atas basis, didiamkan selama 1 menit dan dicatat diameter penyebaran basis. Percobaan diteruskan tiap kali dengan penambahan beban seberat 50 gram dan dicatat diameter penyebaran basis selama 1 menit.

\section{Uji Daya Lekat Basis}

Sejumlah basis diletakkan di atas gelas objek yang telah ditentukan luasnya. Gelas objek yang lain diletakkan di atas basis tersebut dan ditekan dengan beban $1 \mathrm{~kg}$ selama 5 menit. Gelas objek dipasang pada alat uji, lepaskan beban seberat 80 gram dan dicatat waktu hingga kedua gelas objek terlepas.

Uji Volume Pemisahan dengan Sentrifugasi

Basis dimasukkan dalam tabung sentrifuge berskala sampai skala tertentu kemudian diputar dalam sentrifuge pada kecepatan $1000 \mathrm{rpm}$. Volume pemisahan yang terjadi dicatat tiap selang waktu 5 menit sampai menit yang ke-30. Percobaan diulangi untuk tiap kecepatan pemutaran 2000 rpm dan 3000 rpm. 
Tabel II. Formula Sediaan Tabir Surya

\begin{tabular}{cccc}
\hline Formula & Basis & Oksibenson & Ekstrak \\
\hline Formula 1 & + & - & - \\
Formula 2 & + & $6 \%$ & - \\
Formula 3 & + & - & $4 \%$ \\
Formula 4 & + & - & $6 \%$ \\
Formula 5 & + & - & $8 \%$ \\
Formula 6 & + & $6 \%$ & $4 \%$ \\
Formula 7 & + & $6 \%$ & $6 \%$ \\
Formula 8 & + & $6 \%$ & $8 \%$ \\
\hline
\end{tabular}

$\frac{\text { volume emulsi yang memisah }}{\text { volume emulsi keseluruhan }} \times 100 \%$

Uji Volume Pemisahan dengan Sedimentasi Basis dimasukkan ke dalam 2 tabung reaksi berskala sampai skala tertentu. Tabung reaksi berskala berisi basis disimpan masingmasing pada suhu $50^{\circ} \mathrm{C}$ dan suhu kamar. Volume pemisahan basis pada suhu $50^{\circ} \mathrm{C}$ dicatat tiap selang waktu 5 menit sampai menit ke-30. Volume pemisahan basis pada suhu kamar dicatat tiap dua hari sekali sampai hari ke-40. Volume pemisahan dapat dihitung dengan menggunakan rumus pada persamaan (1).

Formulasi dan Analisis Sediaan Tabir Surya Formulasi Sediaan Tabir Surya

Dari uji pendahuluan yang telah dilakukan, dipilih satu formula basis yang mempunyai sifat paling memenuhi persyaratan untuk dibuat sediaan tabir surya. Sediaan tabir surya dibuat dalam 8 formula baru dengan komponen (Tabel II).

Penetapan Mutu Fisik Sediaan

Mutu fisik sediaan tabir surya meliputi organoleptis (bentuk, warna, bau, dan tekstur), pH, dan viskositas. Tujuan dari penetapan mutu fisik sediaan adalah untuk mengetahui kelayakan penggunaan sediaan tabir surya.

Penetapan Persen Transmisi Eritema (\%Te) dan Transmisi Pigmentasi (\%Tp)

Ditentukan secara spektrofotometri dengan pelarut isopropanol pada rentang panjang gelombang 292,5-372,5 nm. Nilai transmisi eritema dihitung dengan mengalikan nilai transmisi (T) dengan faktor efektivitas eritema ( $\mathrm{Fe}$ ) seperti terlihat pada persamaan (Cumpelik, 1972).

Nilai transmisi pigmentasi dihitung dengan cara mengalikan nilai transmisi (T) dengan faktor efektivitas pigmentasi (Fp) sepertsi terlihat pada persamaan (Cumpelik, 1972).

$$
\begin{aligned}
& \text { \%Transmisi Eritema } \\
& =\frac{\sum \boldsymbol{T} \times \boldsymbol{F e}}{\sum \boldsymbol{F e}} \% \text { Transmisi Pigmentasi }=\frac{\sum \boldsymbol{T} \times \boldsymbol{F p}}{\sum F p}
\end{aligned}
$$

Uji Aktivitas Fotodegradasi Tirosin

Kurva baku tirosin dilakukan dengan membuat berbagai seri kadar larutan tirosin dari larutan induk tirosin 0,05\% meliputi konsentrasi 0,$075 ; 0,100 ; 0,125 ; 0,150 ; 0,175$; 0,200; 0,225; 0,250;0,275 mg/ml, kemudian dilakukan pengukuran absorbansi tirosin menggunakan metode Millon. Pengaruh lama penyinaran terhadap fotodegradasi oleh tirosin dan rhetoflam dilakukan dalam tabung dan detail penambahan serta lamanya penyinaran (Tabel III)

Setelah itu, masing-masing kelompok (beserta blangko) dimasukkan ke dalam kotak penyinaran yang berukuran 73,5 x 48 x 26,5 cm dan dilakukan penyinaran. Di dalam kotak dilengkapi 1 buah lampu UV C 20 watt. Jarak antara tabung dengan lampu $10 \mathrm{~cm}$. Kemudian tirosin sisa ditetapkan absorbansinya. Komposisi bahan dalam tabung perlakuan untuk uji pengaruh ekstrak dan vitamin C terhadap fotodegradasi tirosin (Tabel IV).

Tirosin sisa diukur menggunakan metode Millon. Larutan uji yang telah disinari diambil dan dimasukkan dalam tabung reaksi sebanyak 1 ml. Kemudian, ditambahkan larutan $\mathrm{NaOH} \mathrm{1,2}$ $\mathrm{N}$ sebanyak $1 \mathrm{ml}$ dan diinkubasi dalam waterbath selama 1 jam dengan suhu $60^{\circ} \mathrm{C}$. 
Tabel III. Komposisi Bahan dalam Tiap Tabung Perlakuan pada Uji Pengaruh Lama Penyinaran Terhadap Fotodegradasi Tirosin

\begin{tabular}{ccccc}
\hline $\begin{array}{c}\text { Kelompok } \\
\text { Perlakuan }\end{array}$ & $\begin{array}{c}\text { Tirosin 0,05\% } \\
(\mathbf{m l})\end{array}$ & $\begin{array}{c}\text { Rhetoflam 1\% } \\
(\boldsymbol{\mu l})\end{array}$ & $\begin{array}{c}\text { Aquadest } \\
(\mathbf{m l})\end{array}$ & $\begin{array}{c}\text { Lama Penyinaran } \\
\text { (menit) }\end{array}$ \\
\hline $\mathrm{P}_{0}$ & 2,0 & 600 & ad 5 & 0 \\
$\mathrm{~B}_{0}$ & - & 600 & ad 5 & \\
$\mathrm{P}_{1}$ & 2,0 & 600 & ad 5 & 60 \\
$\mathrm{~B}_{1}$ & - & 600 & ad 5 & \\
$\mathrm{P}_{2}$ & 2,0 & 600 & ad 5 & 120 \\
$\mathrm{~B}_{2}$ & - & 600 & ad 5 & \\
$\mathrm{P}_{3}$ & 2,0 & 600 & ad 5 & 180 \\
$\mathrm{~B}_{3}$ & - & 600 & ad 5 & \\
$\mathrm{P}_{4}$ & 2,0 & 600 & ad 5 & 40 \\
$\mathrm{~B}_{4}$ & - & 600 & ad 5 & \\
$\mathrm{P}_{5}$ & 2,0 & 600 & ad 5 & 300 \\
$\mathrm{~B}_{5}$ & - & 600 & ad 5 & \\
\hline
\end{tabular}

Setelah 1 jam, ditambahkan 1,5 $\mathrm{ml} \mathrm{HgSO}_{4}$ $15 \%$ dalam $\mathrm{H}_{2} \mathrm{SO}_{4} 5 \mathrm{~N}$ dan $1 \mathrm{ml} \mathrm{NaNO} 20,2 \%$, kemudian divortex. Setelah 23 menit, diukur absorbansi larutan dengan spektrofotometer pada operating time dan panjang gelombang maksimum.

\section{Analisis Data}

Data analisis spektrofotometri berupa persen transmisi eritema dan persen transmisi pigmentasi sediaan tabir surya. Data ini menunjukkan pengaruh penambahan ekstrak etanol buah mahkota dewa ke dalam sediaan tabir surya. Data persen transmisi eritema dan pigmentasi dianalisis nonparametrik menggunakan uji KruskalWallis, dilanjutkan dengan uji Mann-Whitney untuk mengetahui perbedaan nilai persen transmisi eritema dan persen transmisi pigmentasi tiap formula menggunakan program SPSS (Statistical Product and Service Solution) for windows versi 15. Kadar fenolik total ekivalen asam galat (EAG) diukur menggunakan metode Folin-Ciocalteu dan aktivitas penghambatan fotodegradasi tirosin dibandingkan dengan vitamin $\mathrm{C}$ pada kadar yang sama yaitu $0,15 \%$.

\section{HASIL DAN PEMBAHASAN}

\section{Hasil Proses Ekstraksi}

Simplisis yang diekstrak sebanyak 600 gram menghasilkan ekstrak kental sebanyak 75,87 gram. Jumlah rendemen yang didapat dari hasil perhitungan sebanyak $12,65 \%$.

\section{Kadar Fenolik Total}

Pembuatan kurva baku asam galat dengan seri kadar ( 9 kadar, 0,1005 s/d 0,9045 $\mathrm{mg} / 100 \mathrm{ml}$ ) terhadap absorbansi pada panjang gelombang $750 \mathrm{~nm}$. Dari data diperoleh persamaan regresi $\mathrm{y}=1,146 \mathrm{x}-0,037(\mathrm{x}=$ kadar asam galat dalam $\mathrm{mg} / 100 \mathrm{ml}$ dan $\mathrm{y}=$ Absorbansi) dan nilai koefisien korelasinya 0,99 (rhitung) yang lebih besar dari $r$ table untuk $\mathrm{n}=$ 9; $P=0,95$ sebesar 0,666 , sehingga persamaan kurva baku diatas dapat digunakan untuk menghitung kadar fenolik total dalam ekstrak mahkota dewa pada penelitian ini (Gambar 1).

Kandungan senyawa fenolik total diekspresikan dengan $\% \mathrm{~b} / \mathrm{b}$ ekivalen asam galat (EAG) karena beum diketahui struktur kimianya dalam ekstrak. Hasil kandungan senyawa fenolik total dari ekstrak buah mahkota dewa (Tabel V).

\section{Uji Pendahuluan Formulasi \\ Uji Mutu Fisik}

Perbedaan viskositas pada tiap formula disebabkan karena perbedaan konsentrasi Span 60 dan Tween 60 sebagai emulgator. Penggunaan Span 60 dikombinasikan dengan Tween 60 dalam berbagai konsentrasi dapat menghasilkan emulsi atau krim minyak dalam air (M/A) atau air dalam minyak (A/M) dengan berbagai konsistensi (Lawrence, 2005). Formula 1 menggunakan Span 60 2\% dan Tween 60 1,5\% menghasilkan sediaan dengan viskositas 105 poise. Formula 2 menggunakan Span 60 1,5\% dan Tween 60 2\% menghasilkan 


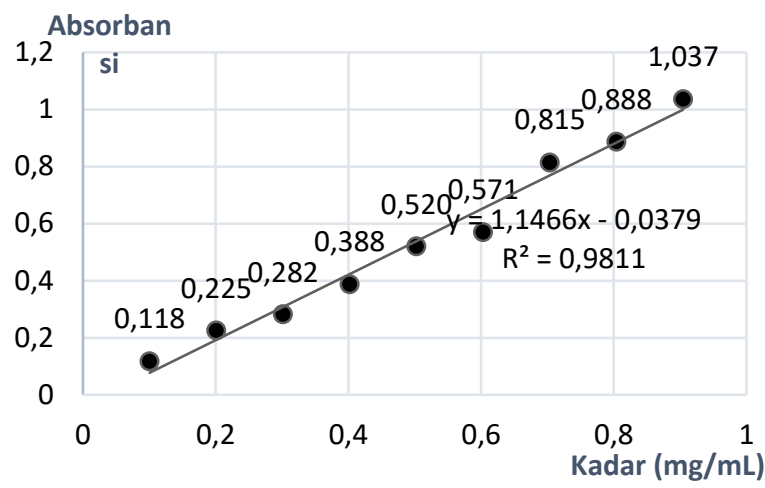

Gambar 1. Kurva Baku Asam Galat

Tabel IV. Komposisi Bahan dalam Tiap Tabung Perlakuan pada Uji Pengaruh Ekstrak dan Vitamin C terhadap Fotodegradasi Tirosin

\begin{tabular}{|c|c|c|c|c|c|}
\hline \multirow[b]{2}{*}{$\begin{array}{l}\text { Kelompok } \\
\text { Perlakuan }\end{array}$} & \multirow[b]{2}{*}{$\begin{array}{c}\text { Tirosin } \\
0,05 \%(\mathrm{ml})\end{array}$} & \multirow[b]{2}{*}{$\begin{array}{c}\text { Rhetoflam } \\
1 \%(\mu \mathrm{l})\end{array}$} & \multicolumn{3}{|c|}{ Isi Bahan dalam Tabung } \\
\hline & & & $\begin{array}{c}\text { Ekstrak Air Buah } \\
\text { Mahkota Dewa } \\
0,15 \%(\mu l) \\
\end{array}$ & $\begin{array}{c}\text { Vitamin C } \\
0,15 \%(\mu l)\end{array}$ & $\begin{array}{l}\text { Aquadest } \\
\text { (ml) }\end{array}$ \\
\hline $\mathrm{P}_{0}$ & 2,0 & - & - & - & ad 5 \\
\hline $\mathrm{B}_{0}$ & - & - & - & - & ad 5 \\
\hline $\mathrm{P}_{1}$ & 2,0 & 600 & - & - & ad 5 \\
\hline $\mathrm{B}_{1}$ & - & 600 & - & - & ad 5 \\
\hline $\mathrm{P}_{2}$ & 2,0 & 600 & - & - & ad 5 \\
\hline $\mathrm{B}_{2}$ & - & 600 & - & - & ad 5 \\
\hline $\mathrm{P}_{3}$ & 2,0 & 600 & 100 & - & ad 5 \\
\hline $\mathrm{B}_{3}$ & - & 600 & 100 & - & ad 5 \\
\hline $\mathrm{P}_{4}$ & 2,0 & 600 & - & - & ad 5 \\
\hline $\mathrm{B}_{4}$ & - & 600 & - & - & ad 5 \\
\hline $\mathrm{P}_{5}$ & 2,0 & 600 & - & 100 & ad 5 \\
\hline $\mathrm{B}_{5}$ & - & 600 & - & 100 & ad 5 \\
\hline
\end{tabular}

Tabel V. Kadar Fenolik Total Ekstrak yang Dihitung sebagai \% b/b EAG

\begin{tabular}{cccc}
\hline Replikasi & Absorbansi M. Dewa & Kadar (\% b/b EAG) \\
\hline 1 & & 0.42 & 8.28 \\
2 & & 0.41 & 8.26 \\
3 & & 0.44 & 8.71 \\
4 & & 0.40 & 7.91 \\
5 & & 0.41 & 8.26 \\
6 & & 0.42 & 8.35 \\
\hline & $\bar{X}$ & 8.29 \\
& $\bar{X} \pm$ LE & & $8.29 \pm 0,27$ \\
& $\mathrm{CV}(\%)$ & 3.08 \\
\hline
\end{tabular}

sediaan dengan viskositas 130 poise. Formula 3 menggunakan Span 60 3,5\% menghasilkan sediaan dengan viskositas 885 poise dan formula 4 menggunakan Tween $60 \quad 3,5 \%$ menghasilkan sediaan dengan viskositas 40 poise. Sediaan krim berwarna krem muda dan krem karena adanya penambahan ekstrak etanolik buah mahkota dewa yang berwarna coklat kehitaman. Hasil uji mutu fisik pendahuluan (Tabel VI). 
Tabel VI. Hasil Uji Mutu Fisik Pendahuluan

\begin{tabular}{lcccc}
\hline Karakter Sediaan & Formula 1 & Formula 2 & Formula3 & Formula 4 \\
\hline Warna & Krem & Krem & Krem Muda & Krem \\
Bau & Khas Mahkota & Khas Mahkota & Khas Mahkota & Khas Mahkota \\
& Dewa & Dewa & Dewa & Dewa \\
Tekstur & Lembut & Lembut & Lembut & Lembut \\
pH & 5 & 5 & 5 & 4 \\
Viskositas & 105 poise & 130 poise & 85 poise & 40 poise \\
\hline
\end{tabular}

Tabel VII. Hasil Uji Daya Lekat

\begin{tabular}{cc}
\hline Formula & Waktu Lekat (detik) \\
\hline 1 & $0,92 \pm 0,35$ \\
2 & $0,70 \pm 0,29$ \\
3 & $0,55 \pm 0,12$ \\
4 & $0,49 \pm 0,03$ \\
\hline
\end{tabular}

\section{Uji Daya Sebar}

Daya sebar paling tinggi dimiliki formula 4, sedangkan daya sebar paling rendah pada formula 1 (Gambar 2). Pada pemberian beban pertama sebesar 55 gram, formula 4 mampu menyebar dengan diameter 4,03 $\mathrm{cm}$ dan pada pemberian beban maksimal 405 gram formula mampu menyebar sampai diameter $6,13 \mathrm{~cm}$. Formula 1 menyebar sampai diameter $2,33 \mathrm{~cm}$ pada pemberian beban 55 gram dan sebesar diameter $3,53 \mathrm{~cm}$ pada pemberian beban 405 gram. Kemampuan daya sebar formula dan formula 3 hampir sama dengan formula 1 . Formula 4 memiliki kemampuan daya sebar berbeda dari ketiga formula tersebut. Semakin besar tahannya berarti semakin sulit sediaan untuk mengalir sehingga daya sebar sediaan semakin kecil. Hal ini terjadi pada penelitian, dimana formula 4 yang memiliki viskositas paling kecil dapat memberikan kemampuan daya sebar yang paling besar.

\section{Uji Daya Lekat}

Pada Tabel VII dapat dilihat daya lekat terbesar dimiliki formula 1 selama 0,92 detik dan daya lekat terkecil pada formula 4 selama 0,49 detik. Kemampuan daya lekat berkaitan dengan densitas dan secara tidak langsung berhubungan dengan viskositas. Semakin besar densitas berarti semakin banyak ikatan antar molekul menyebabkan daya lekat meningkat, sementara semakin besar, semakin tinggi densitas juga menyebabkan meningkatnya viskositas. Dengan kata lain, viskositas menyebabkan kemampuan daya lekat meningkat. Hasil uji daya lekat di atas tidak terlalu sesuai dengan teori karena uji daya lekat dilakukan sesaat setelah sediaan krim selesai dibuat sehingga diduga struktur emulsi belum terbentuk sempurna akibatnya ikatan antar molekul juga belum terbentuk.

\section{Persen Pemisahan dengan Sentrifugasi}

Persen pemisahan secara tidak langsung menunjukkan stabilitas basis terhadap perlakuan fisik yang diberikan. Semakin besar persen pemisahan berarti basis semakin mudah rusak oleh perlakuan, hal ini menunjukkan bahwa basis semakin tidak stabil.

Berdasarkan Gambar 3, 4 dan 5 menunjukkan bahwa formula 2 memiliki kecenderungan memberikan persen pemisahan paling kecil, formula 1 memberikan persen pemisahan lebih besar dari formula 2, dan formula 3 memberikan persen pemisahan lebih besar dari formula 1. Akan tetapi secara keseluruhan baik formula 1, formula 2, maupun formula 3 memberikan persen pemisahan hampir sama. Persen pemisahan pada formula 4 menunjukkan angka paling tinggi bahkan mencapai $100 \%$, jauh berbeda dari nilai yang dihasilkan formula 1, 2, dan 3.

Hasil uji pemisahan deperti di atas dapat terjadi karena ada kaitannya dengan viskositas sediaan. Kecepatan pemisahan fase berbanding terbalik dengan viskositas. Semakin tinggi viskositas krim, kecepatan pemisahan akan semakin lamat dan krim semakin stabil (Rieger, M. M., 1986). Hal ini terjadi pada penelitian dimana formula 2 yang memiliki viskositas paling tinggi cenderung memiliki persen pemisahan paling kecil. Seakin menurun nilai 


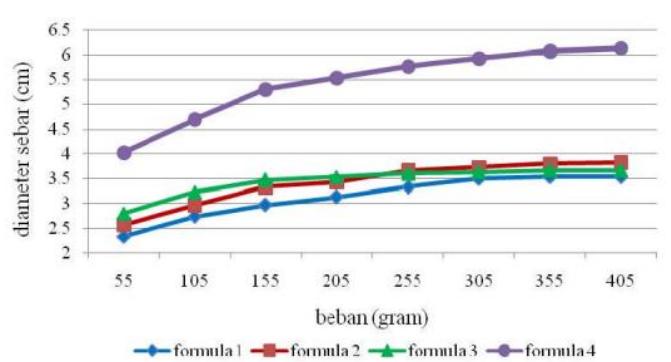

Gambar 2. Grafik Hasil Uji Daya Sebar

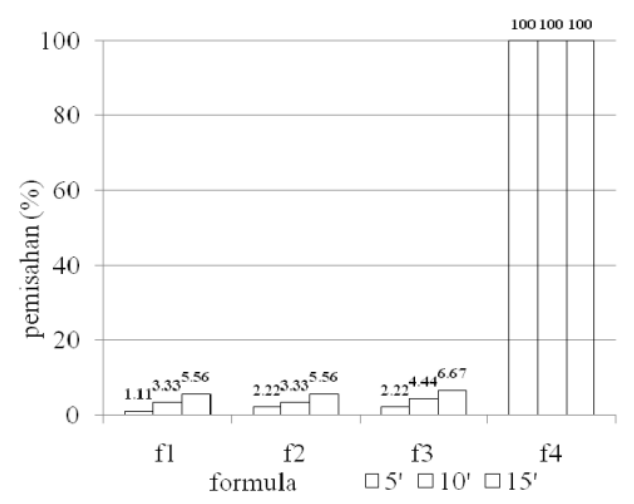

Gambar 3. Histogram Hasil Uji Pemisahan dengan Sentrifugasi $1000 \mathrm{rpm}$

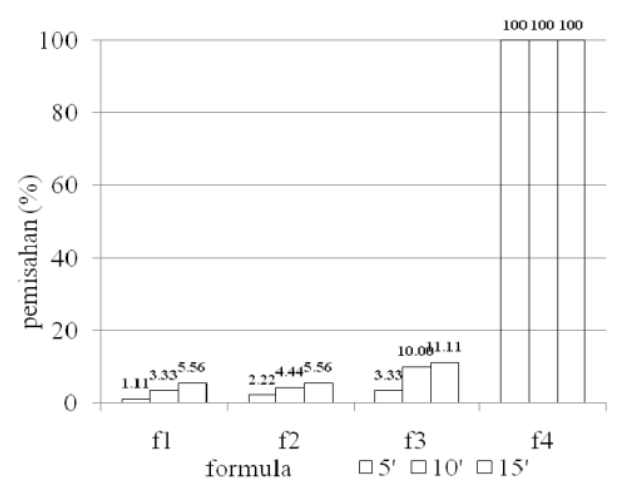

Gambar 4. Histogram Hasil Uji Pemisahan dengan Sentrifugasi $3000 \mathrm{rpm}$

viskositas sediaan seperti pada formula 2 dan formula 3, juga menyebabkan peningkatan persen pemisahan, dan persen pemisahan terbesar terjadi pada formula 4 dimana memiliki viskositas paling rendah.

\section{Uji Persen Pemisahan dengan Sedimentasi Suhu $50^{\circ} \mathrm{C}$}

Uji persen pemisahan pada suhu $50^{\circ} \mathrm{C}$ merupakan salah satu uji stabilitas emulsi pada penyimpanan dipercepat.

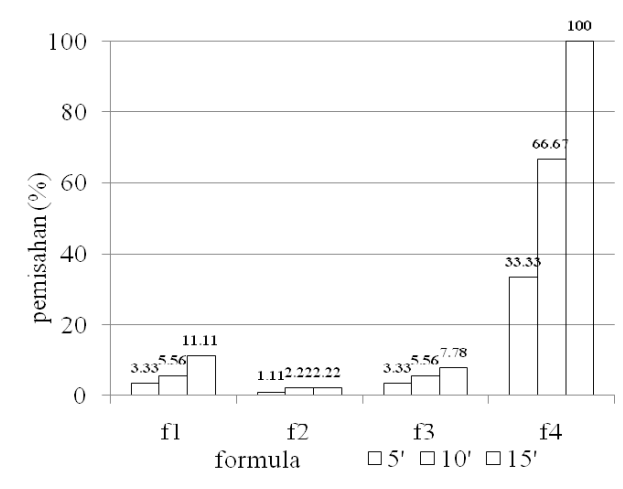

Gambar 5. Histogram Hasil Uji Pemisahan dengan Sentrifugasi $2000 \mathrm{rpm}$

Penyimpanan pada suhu relatif lebih tinggi menyebabkanpenurunan viskositas berdasarkan sifat emulsi yang akan mempengaruhi kestabilan fisika emulsi.

Pada suhu $50^{\circ} \mathrm{C}$ menunjukkan bahwa keempat formula tidak mengendap sampai pengukuran menit ke-30 seperti yang terlihat pada Tabel VIII. Hal ini berarti keempat formula stabil terhadap suhu $50^{\circ} \mathrm{C}$.

Seperti kebanyakan emulsi, keempat formula sediaan menunjukkan kestabilan pada suhu $50^{\circ} \mathrm{C}$ atau suhu kurang dari $55^{\circ} \mathrm{C}$. Efek normal dari umur suatu emulsi pada temperatur yang dinaikkan adalah percepatan laju penggumpalan atau pembentukan krim, dan ini disertai dengan perubahan viskositas. Kebanyakan emulsi menjadi lebih encer bila temperatur dinaikkan dan lebih kental bila dibiarkan pada temperatur kamar (Rieger, M. M., 1986).

\section{Suhu Kamar}

Hasil pengamatan menunjukkan formula paling stabil adalah formula 3. Pada pengamatan hari ke-2, 4, dan 6 formula 3 menunjukkan persen pemisahan sebesar 2,14\%, selanjutnya pada pengamatan hari ke-8 sampai ke-40 persen pemisahan bertahan hanya sebesar $3,57 \%$ yang ditunjukkan dengan kurva linier pada grafik Gambar 6 .

Pada grafik Gambar 6 dapat dilihat formula yang paling tidak stabil adalah formula 4. Pengamatan hari pertama menunjukkan persen pemisahan formula 4 sebesar $0 \%$ atau tidak terjadi kerusakan. Namun pada pengamatan selanjutnya persen pemisahan formula 4 terus meningkat hingga mencapai $12,86 \%$ pada hari ke-40 dimana memiliki 
Tabel VIII. Hasil Uji Persen Pemisahan dengan Sedimentasi pada Suhu $50^{\circ} \mathrm{C}$

\begin{tabular}{ccccc}
\hline \multirow{2}{*}{ Waktu (menit) } & \multicolumn{4}{c}{ Persen Pemisahan } \\
\cline { 2 - 5 } & Formula 1 & Formula 2 & Formula 3 & Formula 4 \\
\hline 5 & Tidak Memisah & Tidak Memisah & Tidak Memisah & Tidak Memisah \\
10 & Tidak Memisah & Tidak Memisah & Tidak Memisah & Tidak Memisah \\
15 & Tidak Memisah & Tidak Memisah & Tidak Memisah & Tidak Memisah \\
20 & Tidak Memisah & Tidak Memisah & Tidak Memisah & Tidak Memisah \\
25 & Tidak Memisah & Tidak Memisah & Tidak Memisah & Tidak Memisah \\
30 & Tidak Memisah & Tidak Memisah & Tidak Memisah & Tidak Memisah \\
\hline
\end{tabular}

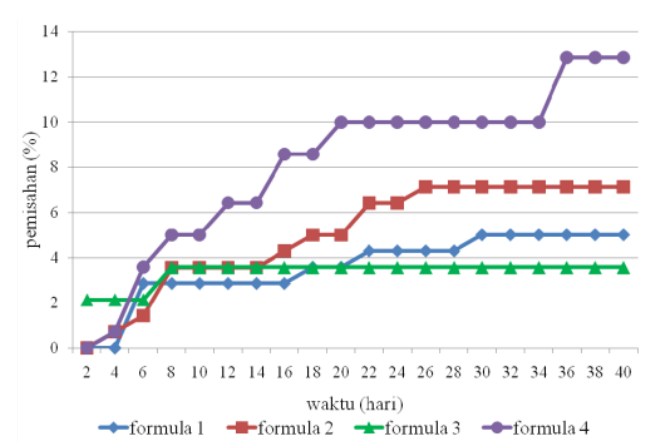

Gambar 6. Grafik Persen Pemisahan dengan Sedimentasi pada Suhu Kamar

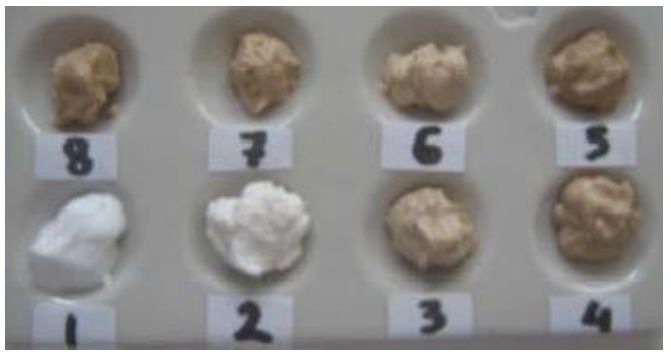

Gambar 7. Formula Sediaan Tabir Surya

Keterangan :

$\begin{array}{ll}\text { 1: Formula } 1 & 5: \text { Formula } 5 \\ \text { 2: Formula 2 } & 6: \text { Formula 6 } \\ \text { 3: Formula 3 } & 7 \text { : Formula 7 } \\ \text { 4: Formula 4 } & 8: \text { Formula }\end{array}$

persen pemisahan terbesar dari keempat formula.

Berdasarkan hasil uji persen pemisahan dengan sedimentasi pada suhu kamar menunjukkan bahwa semakin banyak konsentrasi Span 60 dalam sediaan memberikan persen pemisahan makin kecil. Formula 3 dengan konsentrasi Span 60 3,5\% memberikan persen pemisahan paling kecil. Selanjutnya persen pemisahan meningkat berturut-turut pada formula 1 yang mengandung Span 60 sebanyak 2\%, formula 2 yang mengandung Span 60 sebanyak 1,5\%, dan formula 4 yang tidak mengandung Span 60 .

Menurut Lawrence (2005), Span 60 dapat meningkatkan kemampuan pengikatan air sehingga pada emulsi minyak dalam air seperti sediaan di atas, adanya Span 60 menyebabkan air sebagai medium dispers tarikat lebih kuat pada surfaktan, akibatnya emulsi menjadi stabil.

\section{Formulasi Sediaan Tabir Surya Penentuan Formula Sediaan}

Penampilan fisik dari formula 1, formula 2 , formula 3 , dan formula 4 dan hasil uji mutu fisiknya dapat diterima sebagai sediaan emulsi meliputi tekstur lembut, warna krem, bau khas mahkota dewa, viskositas antara 40-130 poise, pH antara 4-5. Hal ini berarti berdasarkan uji mutu fisik pendahuluan, keempat formula memenuhi kriteria sebagai sediaan krim.

Hasil uji daya sebar keempat formula menunjukkan bahwa dapat diterima, bahkan daya sebar formula 1 , formula 2 , dan formula 3 hampir sama. Kemampuan daya lekat basis dari keempat formula berkisar anara 0,49 detik sampai 0,92 detik, memiliki daya lekat baik dan dapat diterima sehingga keempat formula dapat dipertimbangkan untuk formulasi lebih lanjut.

Perlakuan sentrifugasi pada kecepatan $1000 \mathrm{rpm}, 2000 \mathrm{rpm}$, dan $3000 \mathrm{rpm}$ dalam waktu 5-15 menit memberikan hasil uji pemisahan pada formula 1 , formula 2 , dan formula 3 dengan persen pemisahan hampir sama dan masih dapat diterima sebagai sediaan stabil, yaitu berkisar antara 1,11\% sampai 11,11\%. Formula 4 memberikan persen pemisahan cukup besar antara 33,33\% - 100\%, artinya formula 4 tidak stabil terhadap tekanan mekanik akibat sentrifugasi sehingga praktis tidak dipertimbangkan untuk digunakan dalam formulasi lebih lanjut.

Pada uji pemisahan dengan sedimentasi pada suhu $50^{\circ} \mathrm{C}$, keempat formula tidak 
Tabel IXa. Hasil Uji Mutu Fisik Sediaan Tabir Surya

\begin{tabular}{|c|c|c|c|c|}
\hline $\begin{array}{c}\text { Karakteristik } \\
\text { Fisika }\end{array}$ & F1 & F2 & F3 & F4 \\
\hline Bentuk & Krim & Krim & Krim & Krim \\
\hline Warna & Putih & Putih Tulang & Coklat Pucat & Coklat Muda \\
\hline Bau & Berbau & Tidak Berbau & $\begin{array}{c}\text { Khas Mahkota } \\
\text { Dewa }\end{array}$ & $\begin{array}{c}\text { Khas Mahkota } \\
\text { Dewa }\end{array}$ \\
\hline Tekstur & Lembut & Lembut & Lembut & Lembut \\
\hline $\begin{array}{l}\text { Viskositas } \\
\text { (poise) }\end{array}$ & $47-48$ & $70-80$ & $120-130$ & $120-130$ \\
\hline $\mathrm{pH}$ & 5 & 6 & 5 & 5 \\
\hline
\end{tabular}

Tabel IXb. Hasil Uji Mutu Fisik Sediaan Tabir Surya

\begin{tabular}{|c|c|c|c|c|}
\hline $\begin{array}{c}\text { Karakteristik } \\
\text { Fisika }\end{array}$ & F5 & F6 & F7 & F8 \\
\hline Bentuk & Krim & Krim & Krim & Krim \\
\hline Warna & Coklat Susu & Coklat Pucat & Coklat Muda & Coklat Susu \\
\hline $\mathrm{Bau}$ & $\begin{array}{c}\text { Khas } \\
\text { Mahkota } \\
\text { Dewa }\end{array}$ & $\begin{array}{c}\text { Khas Mahkota } \\
\text { Dewa }\end{array}$ & $\begin{array}{c}\text { Khas Mahkota } \\
\text { Dewa }\end{array}$ & $\begin{array}{c}\text { Khas Mahkota } \\
\text { Dewa }\end{array}$ \\
\hline Tekstur & Lembut & Lembut & Lembut & Lembut \\
\hline $\begin{array}{l}\text { Viskositas } \\
\text { (poise) }\end{array}$ & 100 & 130 & 130 & 90 \\
\hline $\mathrm{pH}$ & 5 & 5 & 5 & 5 \\
\hline
\end{tabular}

memisah. Artinya keempat formula stabil pada suhu $50^{\circ}$ C. Uji pemisahan dengan sedimentasi dalam suhu kamar yang dilakukan selama $\quad 40$ hari dengan waktupengamatan tiap 2 hari sekali menunjukkan bahwa formula 3 paling stabil karena memberikan persen pemisahan paling kecil, bahkan cenderung tidak memisah setelah hari ke-8 sehingga formula 3 dipilih untuk digunakan dalam formulasi sediaan krim selanjutnya.

Berdasarkan semua uji pendahuluan yang telah dilakukan menunjukkan bahwa formula 3 paling memenuhi syarat untuk digunakan dalam pembuatan sediaan tabir surya. Formula 3 memiliki hasil uji mutu fisik baik, daya sebar basis baik, daya lekat basis baik, dan memiliki stabilitas paling tinggi di antara keempat formula. Pada tahap selanjutnya, formula 3 digunakan sebagai basis untuk pembuatan 8 jenis sediaan tabir surya baru.

\section{Hasil Uji Mutu Fisik Sediaan}

Mutu fisik sediaan tabir surya meliputi organoleptis (bentuk, warna, bau, dan tekstur), $\mathrm{pH}$, dan viskositas. Tujuan dari penetapan mutu fisik sediaan adalah untuk mengetahui kelayakan penggunaan sediaan tabir surya. Hasil uji mutu fisik sediaan tabir surya (Tabel IX dan Gambar 7).

\section{Analisis secara Spektrofotometri Hasil Perhitungan \%Transmisi Eritema (\%Te)}

Data hasil perhitungan persen transmisi eritema dari 8 formula dengan 5 replikasi di analisis dengan uji Kolmogorov-Smirnov untuk mengetahui apakah data terdistribusi normal atau tidak. Hasil analisis menunjukkan data hasil perhitungan persen transmisi eritema tidak terdistribusi normal dengan signifikansi $0,014(\alpha<0,05)$ dengan tingkat kepercayaan $95 \%(p=0,05)$. Sampel yang tidak terdistribusi 
Tabel X. Pengaruh Penambahan Ekstrak Etanolik Buah Mahkota Dewa dan Oksibenson dalam Sediaan Tabir Surya terhadap \%Te

\begin{tabular}{cccc}
\hline \multirow{2}{*}{ Formula } & Tansmisi Eritema (\%) & \multicolumn{2}{c}{$\begin{array}{c}\text { Jumlah Komponen yang } \\
\text { ditambahkan (\%) }\end{array}$} \\
\cline { 3 - 4 } & & Oksibenson & Ekstrak \\
\hline 1 & $99,21 \pm 0,25$ & - & - \\
2 & $1,15.10^{-5} \pm 1,45.10^{-5}$ & - & - \\
3 & $37,01 \pm 7,59$ & - & 6 \\
4 & $17,86 \pm 1,42$ & - & 8 \\
5 & $20,29 \pm 1,93$ & 6 & 4 \\
6 & $0,52 \pm 0,27$ & 6 & 6 \\
7 & $0,42 \pm 0,07$ & 6 & 8 \\
8 & $0,17 \pm 0,14$ & & \\
\hline
\end{tabular}

normal selanjutnya dianalisis non-parametik dengan uji Kruskal-Wallis untuk menegtahui apakah sampel berbeda bermakna antar kelompok, kemudian dianalisis lagi menggunakan uji Mann-Whitney untuk persen transmisi eritema dimana menunjukkan bahwa formula 4 tidak berbeda secara bermakna dengan formula 5 , formula 6 tidak berbeda secara berbeda secara bermakna dengan formula 7, dan formula 6 tidak berbeda secara bermakna dengan formula 8.

Berdasarkan Tabel $X$, dapat dilihat bahwa formula 1 dimana hanya berisi basis mempunyai transmisi eritema 99,21 $\pm 0,25 \%$. Hal ini berarti sebagian besar sinar UV B saat mengenai sediaan diteruskan (tidak diserap). Semakin besar \%Te artinya semakin besar sinar UV B dapat diteruskan, sehingga kemungkinan menimbulkan eritema juga semakin besar. Oleh karena itu dapat dikatakan basis tabir surya belum memiliki kemampuan sebagai fotoprotektor UV karena tidak mampu melindungi kulit dari sinar UV.

Pada formula 3, formula 4, dan formula 5 dengan penambahan ekstrak buah mahkota dewa, \% Te mengalami penurunan 0,18-0,37 kali dibandingkan formula 1 , menunjukkan bahwa penambahan ekstrak etanolik buah mahkota dewa dapat meningkatkan kemampuan menghambat radiasi sinar UV B adalah 62,99$82,14 \%$. Namun demikian penambahan ekstrak etanolik buah mahkota dewa belum mampu memberikan perlindungan terhadap sinar UV B karena memiliki \%Te > 18\% padahal kemampuan tabir surya dianggap baik jika memiliki \%Te 1-18\% (Cumpelik, 1972). Jika dibandingkan dengan formula 2 , penambahan oksibenson pada sediaan tabir surya memberikan transmisi eritema $1,15.10^{-5} \pm$ $1,45.10^{-5} \%$, artinya sediaan dengan oksibenson mampu menyerap sebagian besar sinar UV. Nilai ini lebih kecil dibandingkan \%Te dimana terdapat penambahan ekstrak etanolik buah mahkota dewa pada konsentrasi hampir sama. Artinya ekfektivitas fotoproteksi sediaan tabir surya mengandung oksibenson lebih tinggi dibandingkan efektivitas fotoproteksi sediaan tabir surya dengan ekstrak etanolik buah mahkota dewa. Oksibenson merupakan salah satu zat aktif fotoprotektor dan sering digunakan dalam sediaan tabir surya. Kemampuan fotoproteksi ekstak etanolik buah mahkota dewa lebih rendah dari oksibenson karena dalam ekstrak terdapat bermacammacam senyawa, tidak hanya senyawa dalam kaitannya sebagai fotoprotektor tetapi juga senyawa lain termasuk zat ballast sehingga kadar senyawa fotoprotektor dalam ekstrak kecil dan belum mampu memberikan perlindungan yang sama dengan oksibenson.

Pada formula 6, formula 7, dan formula 8 menunjukkan bahwa ketika dikombinasikan dengan oksibenson, penambahan ekstrak etanolik buah mahkota dewa pada sediaan dapat memberikan transmisi eritema 0,171,52\%. Hal ini berarti sediaan memiliki kemampuan memberikan perlindungan terhadap sinar UV B (Cumpelik, 1972). Kombinasi oksibenson dan ekstrak ini memberikan transmisi eritema lebih besar daripada sediaan yang hanya diberi oksibenson. Hal ini diduga ada kaitannya dengan pengaruh interaksi oksibenson terhadap komponen tertentu dalam ekstrak etanolik buah mahkota 
Tabel XI. Pengaruh Penambahan Ekstrak Etanolik Buah Mahkota Dewa dan Oksibenson dalam Sediaan Tabir Surya terhadap \% Tp

\begin{tabular}{cccc}
\hline \multirow{2}{*}{ Formula } & $\begin{array}{c}\text { Transmisi } \\
\text { Pigmentasi (\%) }\end{array}$ & \multicolumn{2}{c}{$\begin{array}{c}\text { Jumlah Komponen yang Ditambahkan } \\
\text { (\%) }\end{array}$} \\
\cline { 3 - 4 } & $49,69 \pm 0,06$ & Oksibenson & Ekstrak \\
\hline 1 & $0,67 \pm 0,10$ & - & - \\
2 & $22,64 \pm 4,16$ & - & - \\
3 & $12,07 \pm 0,90$ & - & 4 \\
4 & $13,87 \pm 1,18$ & - & 6 \\
5 & $3,95 \pm 0,80$ & 6 & 8 \\
6 & $4,48 \pm 0,46$ & 6 & 4 \\
7 & $2,10 \pm 0,61$ & 6 & 8 \\
8 & & & \\
\hline
\end{tabular}

dewa sehingga dapat menurunkan aktivitasnya sebagai fotoprotektor.

\section{Hasil Perhitungan \%Transmisi Pigmentasi (\%Tp)}

Data hasil perhitungan persen transmisi pigmentasi dari 8 formula dengan 5 replikasi di analisis dengan uji Kolmogorov-Smirnov untuk mengetahui apakah data terdistribusi normal atau tidak. Hasil analisis menunjukkan data hasil perhitungan persen transmisi pigmentasi tidak terdistribusi normal dengan signifikan $0,034(\alpha<0,05)$ dengan tingkat kepercayaan $95 \%(\mathrm{p}=0,05)$.

Sampel tidak terdistribusi normal selanjutnya dianalisis nonparametik dengan uji Kruskal-Wallis untuk mengetahui apakah sampel berbeda bermakna antar kelompok, kemudian dianalisis lagi menggunakan uji Mann-Whitney untuk mengetahui kelompok yang berbeda makna. Hasil uji Mann-Whitney untuk persen transmisi pigmentasi hampir sama dengan persen eritema, formula 4 tidak berbeda secara bermakna dengan formula 5 dan formula 6 tidak berbeda secara bermakna dengan formula 7.

Berdasarkan Tabel XI dapat dilihat bahwa formula 1 dimana hanya berupa basis memberikan transmisi pigmentasi 49,69 \pm $0,06 \%$. Semakin besar \%Tp artinya semakin besar sinar UV A dapat diteruskan, sehingga kemungkinan menimbulkan pigmentasi juga semakin besar. Hal ini menunjukkan bahwa basis sediaan tabir surya mampu menyerap sebagian sinar UV A yang menyebabkan pigmentasi pada kulit.

Pada formula 3, formula 4, dan formula 5 dengan penambahan ekstrak etanolik buah mahkota dewa, \%Tp mengalami penurunan 0,24-0,46 kali dibandingkan formula 1 , menunjukkan bahwa penambahan ekstrak etanolik buah mahkota dewa dapat meningkatkan kemampuan menghambat radiasi sinar UV A. Penambahan ekstrak etanolik buah mahkota dewa pada sediaan tabir surya dianggap mampu memberikan perlindungan terhadap sinar UV A karena memiliki \%Tp 3-86\% (Cumpelik, 1972).

Penambahan oksibenson pada formula 2 memberikan transmisi pigmentasi 0,67 \pm $0,10 \%$, menunjukkan bahwa oksibenson mampu menyerap sebagian besar sinar UV A. Nilai ini lebih kecil dibandigkan \%Tp yang disebabkan oleh penambahan ekstrak etanolik buah mahkota dewa pada konsentrasi hampir sama. Artinya efektivitas fotoproteksi sediaan tabir surya dengan oksibenson lebih tinggi dibandingkan efektivitas fotoproteksi sediaan tabir surya dengan ekstrak etanolik buah makota dewa.

Transmisi pigmentasi pada formula 6, 7, dan 8 adalah 2,10-3,95\% ketika oksibenson dikombinasikan dengan penambahan ekstrak etanolik buah mahkota dewa. Hal ini berarti sediaan memiliki kemampuan memberikan perlindungan terhadap sinar UV A (Cumpelik, 1972). Kombinasi oksibenson dan ekstrak ini memberikan transmisi pigmentasi lebih besar 


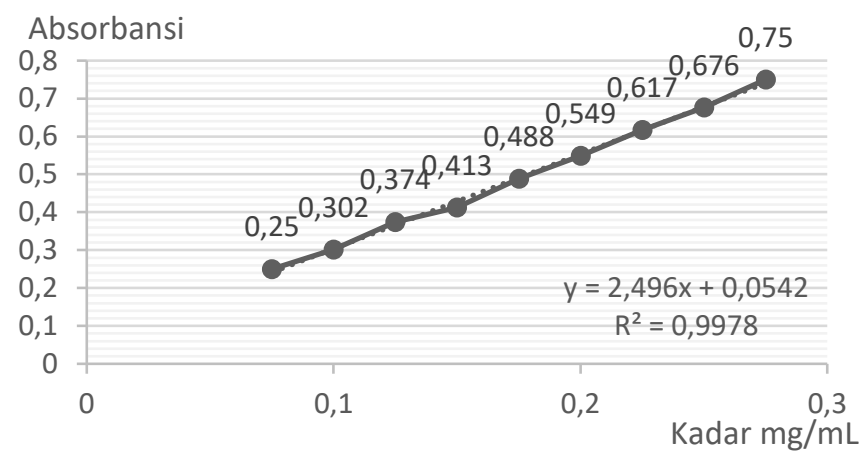

Gambar 8. Kurva Baku Tirosin

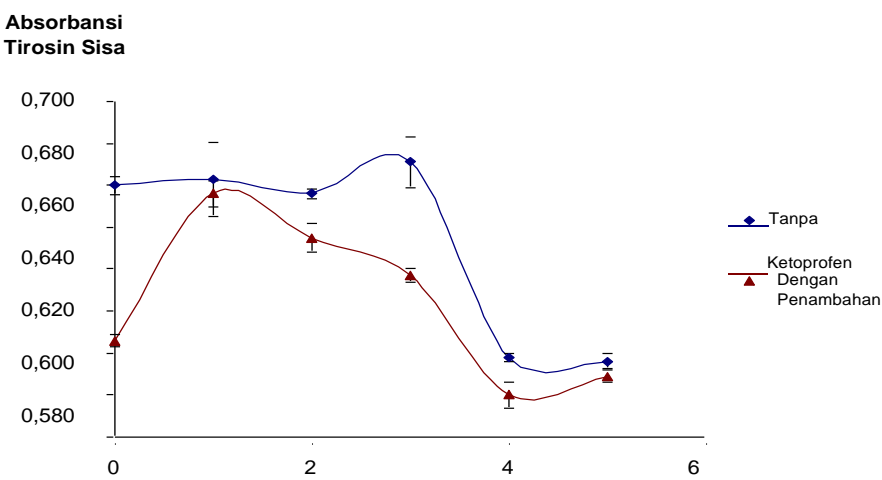

Gambar 9. Kurva Hubungan Lama Penyinaran Lampu UV terhadap Absorbansi Tirosin Sisa

Tabel XII. Absorbansi tirosin sisa pada masing-masing kelompok perlakuan setelah penyinaran 4 jam diukur pada $\lambda 492 \mathrm{~nm}$

\begin{tabular}{ccccc}
\hline \multirow{2}{*}{ Replikasi } & \multicolumn{4}{c}{ Absorbansi perlakuan } \\
\cline { 2 - 5 } & P1 & P2 & P3 & P4 \\
\hline 1 & 0,586 & 0,540 & 0,592 & 0,573 \\
2 & 0,580 & 0,545 & 0,590 & 0,565 \\
3 & 0,586 & 0,544 & 0,593 & 0,575 \\
4 & 0,581 & 0,543 & 0,592 & 0,585 \\
5 & 0,579 & 0,537 & 0,595 & 0,575 \\
6 & 0,578 & 0,536 & 0,594 & 0,568 \\
Rerata & 0,582 & 0,541 & 0,593 & 0,574 \\
Standar Deviasi & 0,004 & 0,004 & 0,002 & 0,007 \\
Standar Deviasi Relatif & 0,602 & 0,696 & 0,30 & 1,207 \\
(\%) & & &
\end{tabular}

daripada sediaan dengan kandungan oksibenson saja. Artinya oksibenson memberikan efektivitas proteksi terhadap sinar UV A lebih tinggi dibandingkan kombinasi oksibenson dan ekstrak. Hal ini diduga bahwa ada kaitannya dengan pengaruh interaksi oksibenson terhadap komponen tertentu dalam ekstrak etanolik buah mahkota dewa sehingga dapat menurunkan aktivitasnya sebagai fotoprotektor. Akan tetapi belum diketahui komponen apa yang dapat berinteraksi dengan oksibenson tersebut. 


\section{Pengaruh Lama Penyinaran Fotodegradasi Tirosin}

Sembilan kadar tirosin terhadap absorbansinya dibuat kurva baku dan dihitung linearitasnya (Gambar 8). Persamaannya adalah $\mathrm{y}=2,496 \mathrm{x}+0,0542$ dengan nilai koefisien korelasinya ( $\mathrm{r}$ hitung $=0,9978$ ). Pengaruh lama penyinaran $(0,60,120,180,240$ dan 300 menit $)$ terhadap fotodegradasi tirosin menunjukkan bahwa nilai absorbansi terkecil ditunjukkan pada pejanan lampu UV selama 4 jam (Gambar 9). Karena nilai absorban berbanding lurus dengan kadar tirosin sisa maka ini berarti fotodegradasi tirosin optimal pada penyinaran selama 4 jam. Dengan demikian pejanan selama 4 jam dijadikan dasar pemejanan lampu UV selanjutnya dalam penelitian ini.

\section{Aktivitas Inhibisi Fotodegradasi Tirosin Ekstrak Buah Mahkota Dewa}

Hasil pengukuran absorbansi tirosin pada berbagai kelompok perlakuan (Tabel XII) dan hasil analisis statistik menunjukkan bahwa ekstrak air buah mahkota dewa mampu menghambat secara signifikan fotodegradasi tirosin yang diinduksi ketoprofen. Aktivitas inhibisi ekstrak dibandingkan dengan vitamin $\mathrm{C}$ memiliki nilai sebesar 1,58. Aktivitas inhibisi ekstrak dibandingkan dengan vitamin C: Ekstrak air Buah Mahkota Dewa

$$
=\frac{P 3-P 2}{P 6-P 2}=\frac{0,593-0,541}{0,574-0,541}=\frac{0,523}{0,033}=1,58
$$

Ekstrak air dari buah mahkota dewa menunjukkan adanya aktivitas inhibisi fotodegradasi tirosin dalam kaitannya dengan aktivitas fotoproteksi. Ekstrak tersebut mampu menghambat fotodegradasi tirosin terhadap sinar UV pada nilai inhibisi sebesar 1,58.

Ekstrak etanol dan ekstrak air buah mahkota dewa sama-sama menggunakan pelarut polar, tetapi dalam formulasi

sediaan tabir surya digunakan ekstrak etanol buah mahkota dewa. Hal ini disebabkan oleh kekhawatiran tumbuhnya jamur atau mikroba yang lain apabila dalam formulasi sediaan tabir surya digunakan ekstrak air buah mahkota dewa.

\section{KESIMPULAN}

Berdasarkan hasil penelitian yang telah dilakukan, ekstrak buah mahkota dewa dapat meningkatkan kemampuan fotoproteksi sediaan tabir surya dengan penurunan \%
0,18-0,37 kali dan penurunan \%Tp 0,24-0,46 kali. Nilai \%Te ekstrak etanolik buah mahkota dewa dalam sediaan tabir surya sebesar 17,86$37,01 \%$ dan nilai \%Tp sebesar 12,07-22,64\%. Nilai ini lebih besar dibandingkan dengan nilai \%Te dan \%Tp oksibenson yaitu 1,15.10-5 \% (\%Te) dan 0,67\% (\%Tp). Sedangkan kandungan fenolik total ekstrak air buah mahkota dewa adalah $8,29 \pm 0,27 \%$ dengan aktivitas penghambatan fotodegradasi tirosin 1,58 kali lebih besar dibandingkan dengan vitamin $\mathrm{C}$ pada kadar sama, yaitu 0,15\%. Hal ini menunjukkan bahwa ekstrak buah mahkota dewa dapat dimanfaatkan sebagai bahan aktif fotoprotektor dalam sediaan kosmetik.

\section{UCAPAN TERIMA KASIH}

Kami mengucapkan terimakasih kepada Frau Prof. Dr. Ulrike Holzgrabe dan Deutscher Akademischer AustauschDienst (DAAD) Jerman yang telah mendanai dan memberi fasilitas beberapa instrumen. Selanjutnya juga diucapkan terimakasih kepada Dekan Fakultas Farmasi dan Ibu Kepala Departemen Kimia Farmasi, UGM atas bantuan serta kemudahan yang diberikan pada penelitian kami.

\section{DAFTAR PUSTAKA}

Barel, A. O. dkk. (2001). Handbook of Cosmetic Science and Technology. New York: Marcel Dekker, Inc.

Cumpelik, B. M. (1972). Analytical Prosedures and Evaluation of Sunscreen. , J.Soc. Cos. Chem.

Halliwel, B. dan Gutteridge, J. M. C. (1999). Free Radical in Biology and Medicine. New York: Oxford Unyversity Press.

Koechevar, N.E., Pathak, M.A., and Pairish, J. A. . (1993). Photophysics, Photochemistry, and Photobiology

(4th Ed). New York: Mc Graw-Hill, Book-Co. Barel, A. O. dkk. (2001). Handbook of Cosmetic Science and Technology. New York: Marcel Dekker, Inc.

Cumpelik, B. M. (1972). Analytical Prosedures and Evaluation of Sunscreen. , J.Soc. Cos. Chem.

Halliwel, B. dan Gutteridge, J. M. C. (1999). Free Radical in Biology and Medicine. New York: Oxford University Press.

Koechevar, N.E., Pathak, M.A., and Pairish, J. A. . (1993). Photophysics, Photochemistry, and Photobiology (4th Ed). New York: Mc Graw-Hill, Book-Co. 
Lawrence, M. J. (2005). Sorbitan Esters (Sorbitan Fatty Acid Esters). London: Pharmaceutical Press.

Rieger, M. M., E. (1986). Emulsion. Philadelphia: Lea and Febiger 600 Washington Square.

Shaath NA (1990). The Chemistry of Sunscreens. In: N.J. Lowe and N.A. Shaath (Eds.). Sunscreens : Development, Evaluation, and Regulatory Aspects. New York: Marcel Dekker, Inc.

Sulaiman, T.N.S., dan Kuswahyuning, R. (2008). Teknologi dan Formulasi Sediaan Semipadat. Yogyakarta: Pustaka Laboratorium Teknologi Farmasi Fakultas Farmasi Universitas Gadjah Mada.
Svobodova, A., J. Psotova., D. W. (2003). Natural Phenolics in the Prevention of UV-Induced Skin Damage. Biomed.

Wasitatmadja, S., M. (1997). Penuntun Ilmu Kosmetik Medik. Jakarta: Universitas Indonesia Press.

Wilkinson, J. B., and Moore, R. J. (1982). The Principles and Practice of Modern Cosmetic. London: Leonard Hill Book.

Zin, Z.M., Hamid, A.A., Osman, A., dan Saari, N. (2004). Antioxidative Activities of Chromatographic Fractions Obtained from Root, Fruit, and Leaf of Mengkudu (Morinda citrifolia L.). Food Chem. 